\title{
Characterization of Somatostatin Specific Binding in Plasma Cell Membranes of Human Placenta
}

\author{
E. TSALIKIAN, T. P. FOLEY, JR., AND D. J. BECKER
}

Department of Endocrinology, Children's Hospital of Pittburgh, Pittsburgh, Pennsylvania 15213

\begin{abstract}
Summary
Somatostatin is a known inhibitor of hormone secretion and of nutrient transport. Because somatostatin-like immunoreactivity has been detected in amniotic fluid and the placenta has both hormone secretory and nutrient transport functions, we investigated the possible existence of somatostatin receptors on placenta cell membranes. Binding of ${ }^{125} \mathrm{I}-\mathrm{Tyr}^{1}$ - and ${ }^{125} \mathrm{I}-\mathrm{Tyr}^{11}$-somatostatin (5-21\%) to solubilized placenta cell membranes was observed. Binding was time-, temperature-, and $\mathrm{pH}$-dependent and occurred maximally with incubation at concentrations of $25 \mu \mathrm{g}$ of membrane protein. Displacement of binding of ${ }^{125} \mathrm{I}-\mathrm{Tyr}^{1}$ and $\mathrm{Tyr}^{11}$ somatostatin by cold cyclic and linear somatostatin and somatostatin analogs Ala-5, Ala-8, and Ala-11 was observed. Scatchard analysis of data revealed high capacity of $\left(R_{o} 0.44 \mathrm{~mol} / \mu \mathrm{g} \times\right.$ $\left.10^{-12}\right)$ but low affinity $\left(K_{\mathrm{d}} 1.8 \mathrm{M} \times 10^{-7}\right)$ binding sites similar to that reported in other tissues. Binding was not reversible under our experimental conditions. The significance of this low affinity binding of somatostatin to placenta cell membranes remains to be determined.
\end{abstract}

\section{Abbreviation}

SRIF, somatostatin

Somatostatin has been shown to have widespread inhibitory actions on the secretion of several hormones (8) and on nutrient transport across the gut $(12,23)$. The placenta is important for both hormone secretion and nutrient transport. The role of somatostatin in the regulation of placental hormone secretion or nutrient transport has not been investigated extensively (17). The abundance of somatostatin in the amniotic fluid (6) and its presence in placental tissue demonstrated by immunohistochemical and extraction techniques $(5,13,19,26)$ suggests a possible role of this hormone on placental function. Because most of the evidence suggests that somatostatin acts on target cells via a membrane receptor site (15), we examined placenta cell membranes for the presence of specific somatostatin receptors. Human placental tissue is readily available and has been previously used to study binding kinetics of polypeptide hormones such as insulin and some of the somatomedins $(10,18)$.

Somatostatin-binding sites have recently been demonstrated in the cell membranes of some of its presumed target tissues, such as the pituitary gland (14), brain neural synaptosomes (14), and pancreatic islet secretory vesicles (25). In addition somatostatin binding to intact cells of the gastric mucosa (20), adipocytes (15), and pituitary cells in culture have been reported (21). In

Received August 30, 1983; accepted March 19, 1984.

Address reprint requests to D. J. Becker, Children's Hospital of Pittsburgh, Division of Pediatric Endocrinology, 125 Desoto Street, Pittsburgh, PA 15213.This work was supported in part by the Heinz Nutrition Fund to the University of Pittsburgh, School of Medicine. the latter, the presence or absence of binding sites correlated with the ability of somatostatin to inhibit growth hormone and prolactin release, thus suggesting that the action of somatostatin may be mediated through binding sites on the cells.

\section{MATERIALS AND METHODS}

Linear and cyclic somatostatins were purchased from Bachem Inc., Marina del Rey, CA. Somatostatin analogs (Ala-5, Ala-8, and Ala-11) were kindly provided by Dr. J. E. Rivier of the Salk Institute. Tyr ${ }^{1}$-somatostatin and $\mathrm{Tyr}^{11}$-somatostatin were purchased from Calbiochem. Other chemicals used were Triton X100 for solubilization of the placenta cell membranes, Bio-Beads SM-2 (Bio-Rad, Inc.) for the removal of the Triton X-100, toluene sulfonyl fluoride (Eastman), charcoal (Fisher), and dextran T-70 (Sigma).

Preparation of membranes. Human placenta from five normal term pregnancies, one 32-week, and one diabetic pregnancy were obtained 10-15 min after delivery and transported on ice. All further procedures were performed at $4^{\circ} \mathrm{C}$. Cell membranes were prepared from all placentas and tested for total and nonspecific binding of somatostatin.

Placental tissue, both fetal and maternal, was minced with scissors and rinsed in cold $(0.3 \mathrm{M})$ sucrose. The tissue was placed in a volume of $0.3 \mathrm{M}$ sucrose equal to $1.5 \times$ tissue volume and homogenized using a Polytron homogenizer. The homogenate was then centrifuged for $10 \mathrm{~min}$ at $600 \times g$, the supernatant was recentrifuged at $12,000 \times g$ for $30 \mathrm{~min}$ and this supernatant was saved. To each $100 \mathrm{ml}$ of supernatant, $0.58 \mathrm{~g}$ of $\mathrm{NaCl}(0.1 \mathrm{M})$ and $4.92 \mathrm{mg} \mathrm{MgSO}_{4}(0.2 \mathrm{mM})$ were added. This solution was centrifuged at $45,000 \times g$ for $45 \mathrm{~min}$; the pellet was washed and resuspended three times in $0.1 \mathrm{M} \mathrm{NaPO}_{4}$ buffer $(\mathrm{pH} 7.4)$. Final pellets were suspended in $10 \mathrm{ml}$ of buffer and gently homogenized in a hand-held glass homogenizer.

The above preparation constituted the particulate cell membranes. Solubilization of the particulate membranes was achieved by the addition of $1 \%$ Triton X-100 and centrifugation at $200,000 \times g$ for $120 \mathrm{~min}$ at room temperature. The supernatant was stored in aliquots at $-70^{\circ} \mathrm{C}$ after removal of Triton X-100 by Bio-Beads SM-2 by the method of Holloway (11). The protein content was determined by the Lowry micromethod (16).

Iodination of Tyr-somatostatin. Both $\mathrm{Tyr}^{1}$ - and $\mathrm{Tyr}^{11}$-somatostatin were iodinated using a modified chloramine-T method (7). Anion-exchange column chromatography using SM52 CMC (8 $\times 1 \mathrm{~cm}$ ) was used for separation of the iodinated hormone from free iodine. Specific activity of about $350 \mathrm{mCi} / \mathrm{mg}$ or $700 \mathrm{Ci} /$ $\mathrm{mmol}$ was achieved. The iodinated hormone was stored at $-70^{\circ} \mathrm{C}$ and thawed only before use. All assays were performed within 10 days of iodination.

Binding Assay. Incubation was carried out in $0.5 \mathrm{ml} 0.05 \mathrm{M}$ Tris buffer with $0.025 \mathrm{M}$ EDTA and $0.5 \%$ bovine serum albumin. The conditions of incubation, i.e. the $\mathrm{pH}$ of the buffer, time, temperature, and membrane concentration, were varied to 
determine an optimal combination. Non-specific binding was determined as the binding observed in the presence of excess (10 $\mu \mathrm{g} /$ tube) unlabeled SRIF in the incubation media. Specific binding was calculated as the difference between nonspecific and total binding.

Concentrations of unlabeled SRIF from 0-5 $\mu \mathrm{g} /$ tube were incubated at $\mathrm{pH} 8$ with $25 \mu \mathrm{g}$ protein for $18 \mathrm{~h}$ in triplicate in order to determine the displacement of label by increasing concentrations of native hormone. After the incubation time was completed, $1 \mathrm{ml}$ of chilled dextran-coated charcoal suspension ( $0.25 \%$ activated charcoal and $0.025 \%$ dextran T-70 in Tris/ EDTA/albumin buffer) was added. Tubes were vortexed and left standing for $30 \mathrm{~min}$ at $4^{\circ} \mathrm{C}$ before centrifugation for $10 \mathrm{~min}$ at $2000 \times g$ at $4^{\circ} \mathrm{C}$. The supernatant was pipetted or poured off and counted. The pellet which represents the free ${ }^{125} \mathrm{I}-\mathrm{Tyr}$-somatostatin was counted separately. The addition of toluene sulfonyl fluoride to the incubation medium slightly increased the stability of the preparation.

Assessment of degradation. Paper electrophoresis and column chromatography were used for assessment of label degradation after incubation with buffer or $25 \mu \mathrm{g}$ membrane protein for 18 $\mathrm{h}$ at $4^{\circ} \mathrm{C}$. Approximately $30 \mu \mathrm{l}$ of solution containing labeled hormone was applied at the origin of paper strips and electrophoresed for 6-7 h at 275 watts on a Beckman paper electrophoresis cell. The paper strip was cut into $1-\mathrm{cm}$ wide perpendicular pieces and each counted separately. Chromatography was performed using a $1 \times 25 \mathrm{~cm}$ Bio-Gel P-30 column and the labeled hormone was eluted with $3 \mathrm{M}$ acetate buffer at $4^{\circ} \mathrm{C}$.

\section{RESULTS}

Specific binding of somatostatin to solubilized term placenta cell membranes was observed. This binding ranged from $5-21 \%$ within and between placentas with a mean of $10 \pm 4 \%$ (SD), and was similar in all five placentas. Specific binding to particulate placenta cell membranes was not observed. Non specific binding with solubilized placenta cell membranes ranged from $6-21 \%$ the total counts with a mean of $13.5 \pm 5.2 \%$ depending mostly on the integrity of the iodination product. Optimal specific binding was achieved at $\mathrm{pH} 8-9$ and at an incubation temperature of $4^{\circ} \mathrm{C}$ for $18 \mathrm{~h}$ using $25 \mu \mathrm{g}$ membrane protein per tube, as will be described below. These conditions were used for all of the assays except if otherwise indicated. Specific binding was similar in the premature and diabetic placentas.
Effect of membrane protein concentration on specific binding. The effect of membrane protein concentration per $0.5 \mathrm{ml}$ of incubation volume on the specific binding of ${ }^{125} \mathrm{I}^{\mathrm{S}} \mathrm{Tyr}^{1}$-somatostatin to solubilized placenta cell membranes was evaluated. The amount of membrane protein varied from 2.5 to $200 \mu \mathrm{g} /$ tube . Specific binding was maximal with $10-25 \mu \mathrm{g}$ membrane protein/ tube and decreased to nonexistent with very low $(2.5 \mu \mathrm{g})$ or very high $(200 \mu \mathrm{g})$ protein concentration per tube. Binding of the labeled hormone was tested over a range of 6,000-100,000 cpm, with optimal binding observed using approximately $25,000 \mathrm{cpm}$. Subsequent studies were performed using $25 \mu \mathrm{g}$ membrane protein and $32.5 \mathrm{pg}$ of labeled hormone per tube.

Effect of incubation time and temperature on specific binding. Specific binding was assessed at three different temperatures for the indicated time intervals. At $23^{\circ} \mathrm{C}$, specific binding was minimal for the whole length of the incubation time period of $18 \mathrm{~h}$. At $37^{\circ} \mathrm{C}$, specific binding was consistently observed by $20 \mathrm{~min}$, reached equilibrium by $160 \mathrm{~min}$, and was stable for 1 additional h. Specific binding of ${ }^{125} \mathrm{I}-\mathrm{Tyr}^{1}$-somatostatin to solubilized placenta cell membranes at $4^{\circ} \mathrm{C}$ reaches equilibrium at $8 \mathrm{~h}$ and remains stable for $18 \mathrm{~h}$.

Effect of $p H$ on specific binding. The effect of $\mathrm{pH}$ on specific binding was assessed by varying the $\mathrm{pH}$ of the incubation media from 4 to 9 at $4^{\circ} \mathrm{C}$ for $18 \mathrm{~h}$. In three separate experiments, specific binding was consistently lowest at $\mathrm{pH} 6$ with optimum binding at $\mathrm{pH} 8$ and 9.

Assessment of degradation of ${ }^{125}$-I-Tyr-somatostatin. Degradation of the labeled hormone in the assay system assessed by paper electrophoresis and column chromatography. The results of the electrophoretic mobility of tracer, ${ }^{125} \mathrm{I}_{-}-\mathrm{Tyr}^{1}$-somatostatin incubated with increasing concentrations of membrane protein in the medium are depicted in Figure 1. Increased degradation of the labeled hormone, defined by the distance from the origin where the sample was applied, compared to control, was observed with increasing concentrations of solubilized membranes. Incubation with $25 \mu \mathrm{g}$ of membrane protein for $18 \mathrm{~h}$ did not affect the migration pattern of ${ }^{125} \mathrm{I}-\mathrm{Tyr}^{1}$-somatostatin when compared to the pattern of labeled somatostatin incubated for the same time period without membrane protein. Similar results were obtained with ${ }^{125} \mathrm{I}_{-T y r}{ }^{11}$-somatostatin.

Following incubation of labeled Tyr ${ }^{1}$-somatostatin for $18 \mathrm{~h}$ with $25 \mu \mathrm{g}$ membrane, most of the radioactivity eluted on column chromatography was in a large peak (upper panel, Fig. 2) comparable to the peak of radioactivity eluted on the same

PAPER ELECTROPHORESIS OF LABELLED SRIF

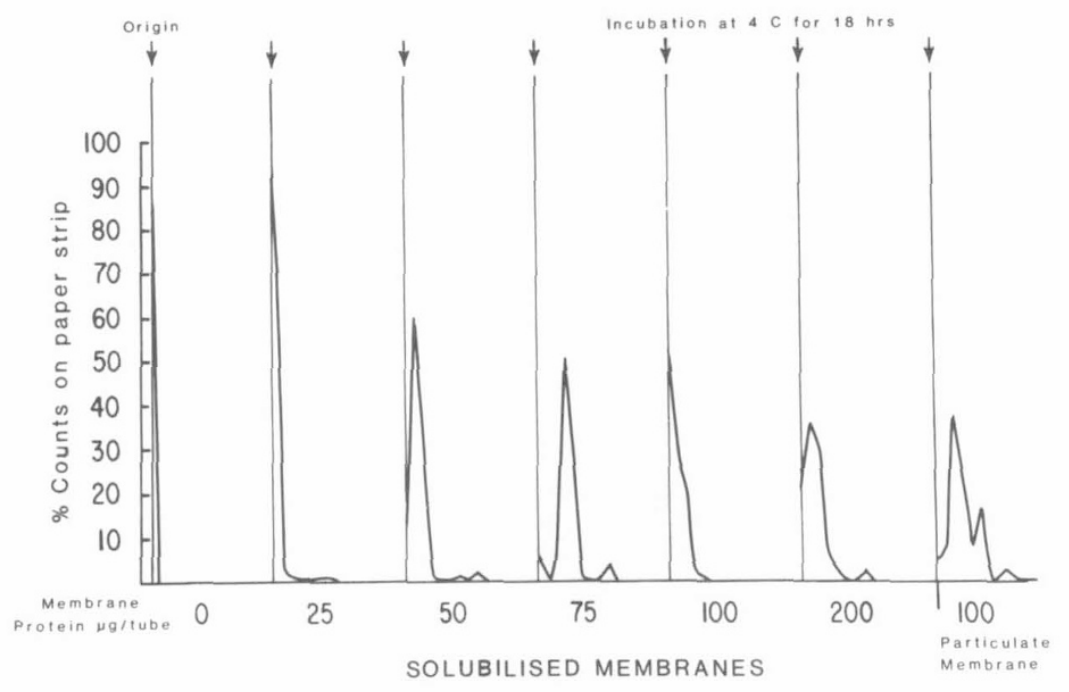

Fig. 1. Paper electrophoretic mobility patterns of ${ }^{125} \mathrm{I}_{-} \mathrm{Tyr}^{1}$-somatostatin incubated with seven different membrane protein concentrations for 18 h at $4^{\circ} \mathrm{C}$. 
column from the labeled somatostatin incubated without membrane protein (lower panel, Fig. 2). The smaller peaks in the upper panel most probably represent membrane-bound labeled somatostatin and a small amount of degradated tracer bound to protein or protein aggregates. Note that the proportion of radioactivity eluted in this area coincides with the approximately $20 \%$ specific binding found using charcoal separation.

Competitive binding. Increasing concentrations of cyclic and linear native somatostatin displaced ${ }^{125} \mathrm{I}^{-\mathrm{Tyr}^{1}}$-somatostatin. The three analogs $\mathrm{Ala}^{5}$-somatostatin, $\mathrm{Ala}^{8}$-somatostatin, and $\mathrm{Ala}^{11}$ somatostatin also displaced ${ }^{125} \mathrm{I}_{-} \mathrm{Tyr}^{1}$-somatostatin (Fig. 3). Similar displacement was shown with somatostatin 28. Scatchard plots of cyclic and linear somatostatin displacement of ${ }^{125} \mathrm{I}_{-} \mathrm{Tyr}^{1}$ somatostatin are depicted in Figure 4. Similarly, cyclic somatostatin displaced ${ }^{125} \mathrm{I}_{-} \mathrm{Tyr}^{11}$-somatostatin. The binding curve and

\section{COLUMN CHROMATOGRAPHY}
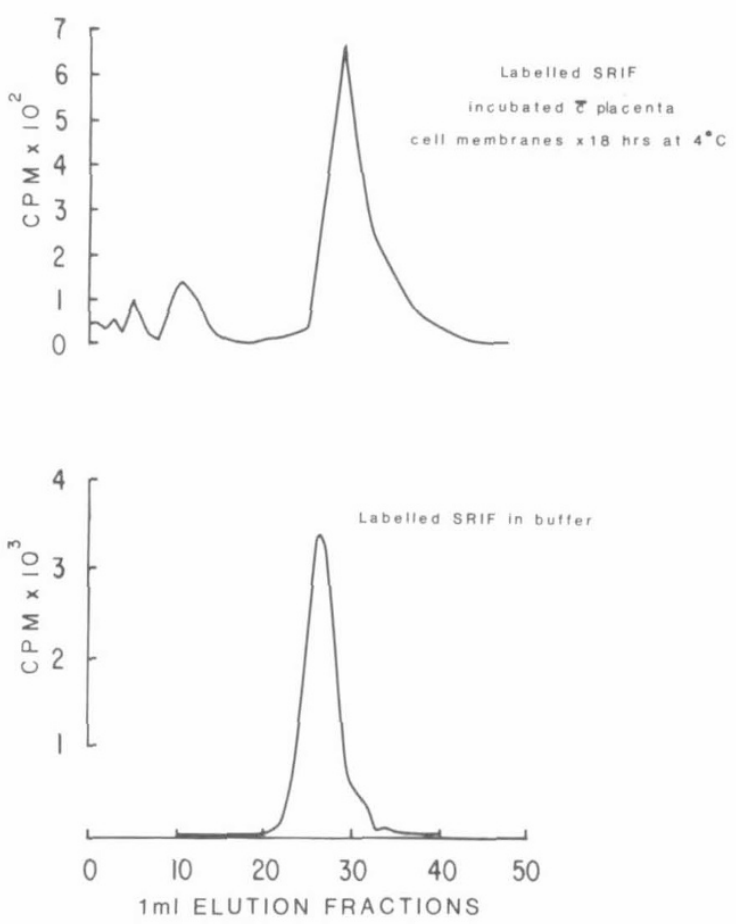

Fig. 2. Bio-Gel P-301 $\times 25 \mathrm{~cm}$ column chromatography of ${ }^{125} \mathrm{I}_{-}-\mathrm{Tyr}^{\mathrm{I}}-$ somatostatin buffer (lower panel) and after incubtion with $25 \mu \mathrm{g}$ membrane protein for $18 \mathrm{~h}$ at $4^{\circ} \mathrm{C}$ (upper panel). Elution buffer was $3 \mathrm{M}$ acetate at $4^{\circ} \mathrm{C}$.
Scatchard plot are depicted in Figure 5. There was no displacement of ${ }^{125} \mathrm{I}_{-} \mathrm{Tyr}^{11}$-somatostatin by other polypeptides such as insulin, growth hormone, and gonadotropin-releasing hormone, although cholecystokinin 10-20 displaced the label in parallel at a 50 times higher concentration while gastric inhibitory polypeptide and cholecystokinin 33 slightly displaced the binding (70\%) at 500 times the concentration.

The capacity $R_{\mathrm{o}}$ and affinity and dissociation constants $K_{\mathrm{a}}$ and $K_{\mathrm{d}}$ of the competitive binding of cyclic and linear somatostatin and somatostatin analogs with the placental membranes displacing both $\mathrm{Tyr}^{1}$ - and $\mathrm{Tyr}^{11}$-somatostatin were calculated. Higher affinity and dissociation constants were noticed with displacement of ${ }^{125} \mathrm{I}_{-} \mathrm{Tyr}^{11}$-somatostatin than those of ${ }^{125} \mathrm{I}^{-\mathrm{Tyr}^{1}}$-somatostatin. Somatostatin analog $\mathrm{Ala}^{8}$-somatostatin had lower $K_{\mathrm{a}}$ and $K_{\mathrm{d}}$ in displacing either label in comparison with the other compounds displacing the same label.

Dissociation of ${ }^{125}$ I-Tyr-somatostatin binding. Solubilized placental membranes, $25 \mu \mathrm{g}$ protein/tube, were incubated with ${ }^{125} \mathrm{I}$ $\mathrm{Tyr}^{11}$-SRIF for $6 \mathrm{~h}$ at which time excess unlabeled SRIF was added. At the end of total $18 \mathrm{~h}$ of incubation, total binding was only $3 \%$ lower than that observed at $18 \mathrm{~h}$ when no cold hormone was added (Fig. 6), indicating either slow dissociation or irreversibility of binding. When cold hormone was added after 18 -h incubation, no decrease in binding appeared after an additional $6 \mathrm{~h}$ of incubation.

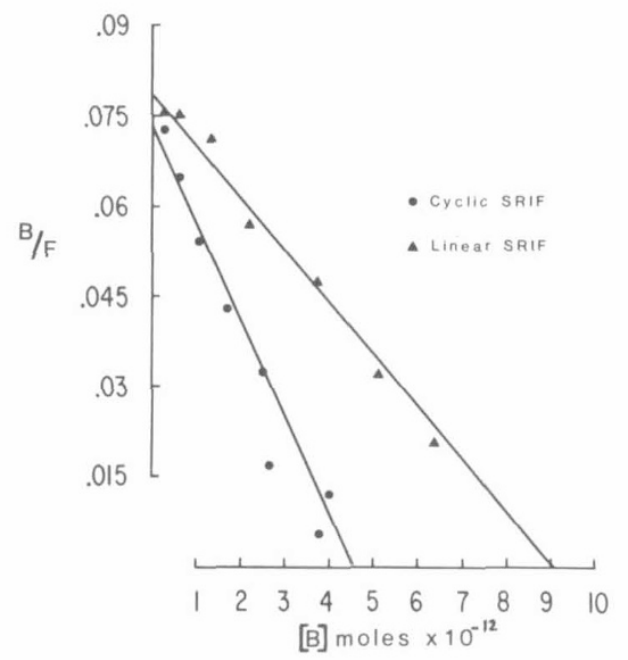

Fig. 4. Scatchard plots of displacement of ${ }^{125} \mathrm{I}^{-\mathrm{Tyr}^{1}}$-somatostatin by cyclic and linear somatostatin.

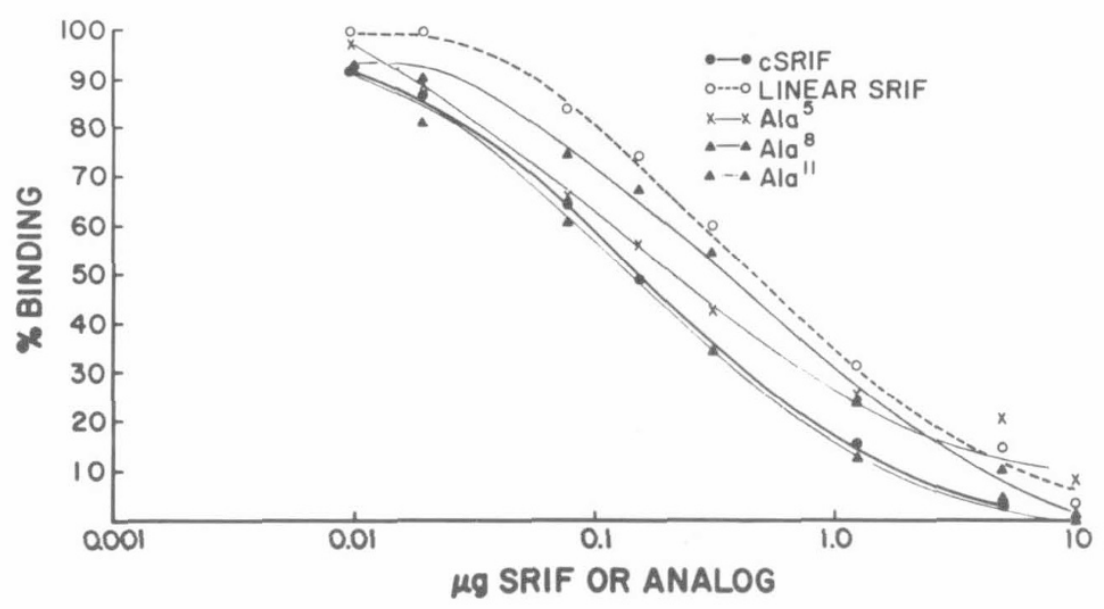

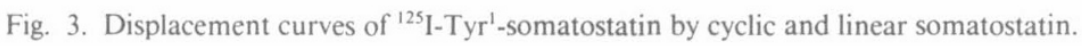




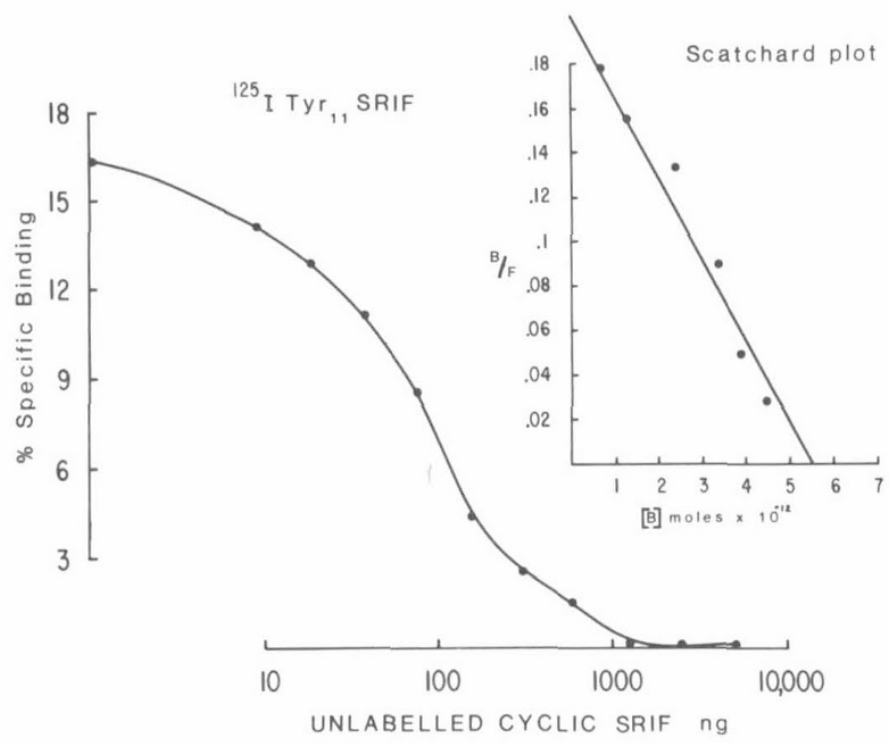

Fig. 5. Displacement curve of ${ }^{125} \mathrm{I}^{-\mathrm{Tyr}^{11}}{ }^{1}$-somatostatin by cyclic somatostatin. The abscissa units are ng/tube. Inset, Scatchard plot of displacement data.

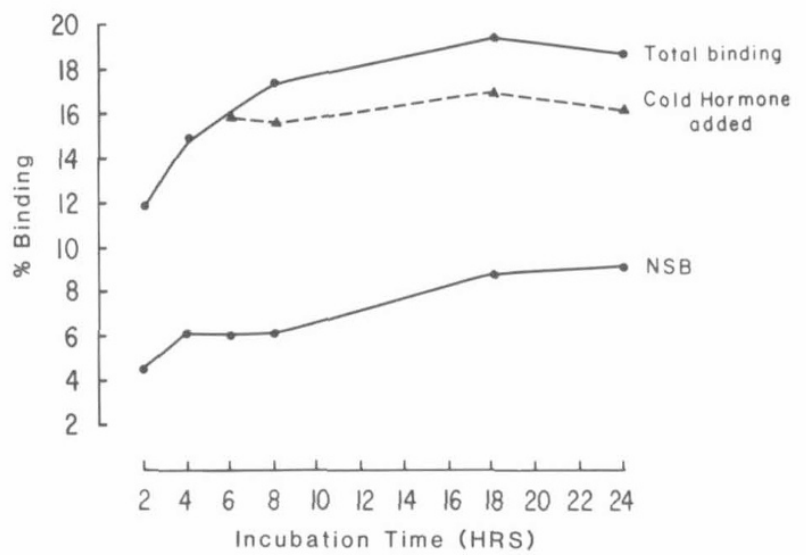

Fig. 6. Total and nonspecific binding and binding after cold hormone was added at 6 -h incubation of ${ }^{125} \mathrm{I}^{-\mathrm{Tyr}^{11}}{ }^{-}$-somatostatin to $25 \mu \mathrm{g}$ of placenta membrane protein incubated at $4^{\circ} \mathrm{C}$ for up to $24 \mathrm{~h}$.

\section{DISCUSSION}

Binding sites for somatostatin have been identified in a number of tissues by demonstrating specific binding of labeled somatostatin to either intact cells or cell membrane preparations. It has been postulated that specific receptor sites exist only on those cells in which somatostatin has been shown to have a biological action (21). However, as is the case with insulin, there is a report of binding to mononuclear leukocytes (3), where there is no known biological action. In the present study, we described specific irreversible binding of somatostatin to placenta, a tissue in which somatostatin may exert a biological response.

Specific binding of somatostatin to the placental membranes was only identified after solubilization of the membranes with Triton X-100. Solubilization of the receptor eliminates proteolytic enzymes from the preparation, which are likely to degrade both the labeled and unlabeled hormone. As was demonstrated for insulin receptors on placenta cell membranes, this procedure does not change the binding characteristics of the receptors (9).

Little or no degradation was observed after incubation of labeled somatostatin with $25 \mu \mathrm{g}$ of membrane protein using paper electrophoresis or column chromatography. As demonstrated by the faster moving label on paper electrophoresis, increased degradation of somatostatin was observed with higher concentrations of membrane protein in the incubation media. This finding suggests that increasing concentrations of membrane protein degraded the iodinated polypeptide. Furthermore, the specific binding observed at the end of $18 \mathrm{~h}$ in the presence of $25 \mu \mathrm{g}$ membrane protein in these studies represents that of the intact hormone and not a degradation product.

The optimal $\mathrm{pH}$ of this assay was found to be between 8 and 9, similar to that observed in somatostatin-binding assays using other tissues (14). Binding was shown at both 4 and $37^{\circ} \mathrm{C}$ with similar binding levels at equilibrium. Optimal time, temperature, and $\mathrm{pH}$ characteristics of this assay are similar to those demonstrated in other reports of somatostatin binding to membranes of other tissues.

We found similar displacement of both ${ }^{125} \mathrm{I}_{-} \mathrm{Tyr}^{1}$ - and $\mathrm{Tyr}^{11}$ somatostatin binding by unlabeled cyclic somatostatin. Although cyclic somatostatin is the physiologic circulating form, similar displacement was shown using linear somatostatin. ${ }^{125} \mathrm{I}-\mathrm{Tyr}^{11}$ somatostatin had higher binding affinity than $\mathrm{Tyr}^{1}$-somatostatin as has been observed in studies with other tissues (24).

Displacement of both ${ }^{125} \mathrm{I}_{-} \mathrm{Tyr}^{1}$-somatostatin and ${ }^{125} \mathrm{I}_{-} \mathrm{Tyr}^{11}$ somatostatin binding to the placenta cell membranes was also observed with three somatostatin analogs. The affinity constants of $\mathrm{Ala}^{5}$-somatostatin and $\mathrm{Ala}^{11}$-somatostatin were very similar to those for cyclic somatostatin, but lower affinity was observed for $\mathrm{Ala}^{8}$-somatostatin. This finding coincides with the observation of Schonbrunn et al. (22) that substitution of residues 6-10 of somatostatin results in decreased affinity.

The affinity constant of somatostatin binding to placenta cell membranes is similar to that observed in membranes from the pituitary cells and in circulating blood cells $(13,21)$. Higher affinity was observed with binding in the $\mathrm{GH}_{4} \mathrm{C}_{1}$ cell line, brain synaptosomal membranes, adrenal capsular, and anterior pituitary membrane-rich particulate fractions $(12,21,24)$. The two latter studies were performed with an iodinated analog which has been more active and more resistant to degradation than the native hormone and, therefore, may have different binding features.

Scatchard plots for somatostatin binding to placental membrane preparation were linear, indicating that these binding sites have the same affinity. Since linear and curvilinear Scatchard plots have been obtained in somatostatin binding assays, target tissues may vary in the number and type of receptors.

The lack of reversibility of somatostatin binding to placenta membranes is disturbing. Reversibility of binding has only occasionally been addressed in other somatostatin-binding studies in the literature. A high percentage of specific binding of the iodinated hormone was irreversible after incubation at either 37 or $4^{\circ} \mathrm{C}$. It is possible that the experimental conditions we followed prevented the phenomenon. Degradation of the labeled peptide could be a reason for the irreversible binding observed, but displacement of the labeled hormone by analogs introduced prior to incubation was in accordance with their previously reported biological activity (4), and this would not occur if the tracer hormone were degraded. Therefore, we do not have a good explanation for these findings.

The significance of the irreversible specific binding of somatostatin to a solubilized placenta cell membrane preparation observed is unclear at the present time. A role for low affinity somatostatin-binding sites in human placenta remains hypothetical; an action of somatostatin on either the placental nutrient transport mechanism or on placental hormonal secretion has not yet been defined. It is possible that the placenta may be an easily obtainable source of tissue for the development of a radioreceptor assay for somatostatin which would, however, only be useful in studying the physiology of this hormone where it exists in high concentrations.

Acknowledgments. The assistance of L. M. Johnson, Ph.D., in completion of these studies and preparation of the manuscript is 
appreciated. The excellent secretarial assistance of Marylee Campion is acknowledged.

\section{REFERENCES}

1. Aguilera G, Parker DS, Catt KJ 1982 Characterization of somatostatin receptors in the rat adrenal glomerular zone. Endocrinology 111:1376

2. Aguilera G, Parker DS 1982 Pituitary somatostatin receptors. J Biol Chem 257:1134

3. Bhathena SJ, Louis J, Schechter GP, Redman RS, Wahl L, Recant L 1981 Identification of human mononuclear leukocytes bearing receptors for somatostatin and glucagon. Diabetes 30:127

4. Brown M, Rivier J, Vale W 1976 Biological activity of somatostatin and somatostatin analogs on inhibition of arginine-induced insulin and glucagon release in the rat. Endocrinology 98:336

5. Fitz-Patrick D, Patel YC 1981 Evidence for somatostatin precursors in human stomach, placenta, and amniotic fluid. J Clin Endocrinol Metab 53:372

6. Fitz-Patrick D, Patel YC 1979 Measurement, characterization, and source of somatostatin-like immunoreactivity in human amniotic fluid. J Clin Invest 64:739

7. Freychet P, Roth J, Neville DM Jr 1971 Monoiodoinsulin: demonstration of its biological activity and binding to fat cells and liver membranes. Biochem Biophys Res Commun 43:400

8. Guillemin R, Gerich J 1976 Somatostatin: physiologic and clinical significance. Annu Rev Med 27:379

9. Harrison LC, Billington T, East IJ, Nichols RJ, Clark S 1978 The effect of solubilization on the properties of the insulin receptor of human placental membranes. Endocrinology 102:1485

10. Haour F, Bertrand J 1974 Insulin receptors in the plasma membranes of human placenta. J Clin Endocrinol Metab 38:334

11. Holloway PW 1973 A simple procedure for removal of Triton X-100 from protein samples. Anal Biochem 53:304

12. Johansson C, Wisen O, Efendic S, Urnas-Wallenstein K 1982 Effect of somatostatin on gastrointestinal propagation and absorption of oral glucose in man. Digestion 22:126
13. Kumusaka T, Nishi N, Yaoi Y, Kido Y, Saito M, Okayasu I, Shimizu H, Hatatzeyama S, Swaro S, Kokobu K 1979 Demonstration of immunoreactive somatostatin-like substance in villi and decidua in early pregnancy. Am J Obstet Gynecol 134:39

14. Leitner WL, Rifkin RM, Maman A, Sussman KE 1979 Somatostatin binding to pituitary plasma membranes. Biochem Biophys Res Commun 87:919

15. Leitner JW, Rifkin RM, Maman A, Sussman KE 1980 The relationship between somatostatin binding and cyclic AMP-stimulated protein kinase inhibition. Metabolism 28:1065

16. Lowry OH, Rosebrough NJ, Farr AL, Randall RJ 1951 Protein measurement with the Folin phenol reagent. J Biol Chem 193:265

17. Macaron C, Kyncl M, Rutsky L, Halpern B, Brewer J 1978 Failure of somatostatin to affect human chorionic somatomammatropin and human chorionic gonadotropin secretion in vitro. J Clin Endocrinol Metab 47:1141

18. Marshall RN, Underwood LE, Voina SJ, Foushee DB, Van Wyk JJ 1974 Characterization of the insulin and somatomedin-C receptors in human placental cell membranes. J Clin Endocrinol Metab 39:283

19. Nishihira M, Yagihashi S 1978 Immunohistochemical demonstration of somatostatin-containing cells in the human placenta. J Exp Med 126:397

20. Reyl F, Silva C, Lewin MJM 1979 Somatostatin receptors on isolated gastric cells. In: Rosselin G, Framageot P, Banfils S (eds) Hormone Receptors in Digestion and Nutrition, pp 391-400. Elsevier/North-Holland, Amsterdam

21. Schonbrunn A, Tashjian AH Jr 1978 Characterization of functional receptors for somatostatin in rat pituitary cells in culture. J Biol Chem 253:6473

22. Schonbrunn A, Rorstad OP, Westendorf JM, Martin JB 1983 Somatostatin analogs: correlation between receptor binding affinity and biological potency in $\mathrm{GH}$ pituitary cells. Endocrinology 113:1559

23. Schusdziarra V, Zyznar E, Rouiller D 1980 Splanchnic somatostatin: a hormonal regulation of nutrient hemostasis. Science 207:530

24. Srikant CB, Patel YC 1981 Somatostatin receptors: identification and characterization in rat brain membranes. Proc Natl Acad Sci USA Neurobiology 78:3930

25. Sussman KE, Leitner JW, Rifkin RM 1978 Somatostatin selective inhibition of cyclic AMP stimulated protein kinase. Trans Assoc Am Physicians 91:129

26. Watkins WB, Yen SSC 1980 Somatostatin in cytotrophoblast of the immature human placenta: localization by immunoperoxidase cytochemistry. J Clin Endocrinol Metab 50:969

\title{
Determination and Characterization of Immunoreactive Trypsin in Amniotic Fluid from Normal and Cystic Fibrosis Fetuses
}

\author{
ANDERS BORGSTRÖM, TOMAS SVEGER, STIG KULLANDER, LARS SVANBERG, AND \\ PETER HÖSLI \\ Departments of Clinical Chemistry [A.B.], Pediatrics [T.S.], and Obstetrics [S.K., L.S.], University of Lund, \\ Malmō General Hospital, Malmö, Sweden and Institut Pasteur, Department of Molecular Biology, Paris, France [P.H.]
}

\section{Summary}

High concentrations of immunoreactive trypsin (IRT) in the blood, and low concentrations of trypsin activity in fecal specimens have been found in newborn infants with cystic fibrosis (CF). The amniotic fluid concentrations of IRT and of IRT in complex with $\alpha_{1}$-antitrypsin $\left(\alpha_{1} \mathrm{AT}\right)$ were studied in 39 samples taken in about the 17th gestational week, and in 7 samples taken because the mothers had previously given birth to children with CF. The midtrimester samples contained trypsin in complex with

Received October 24, 1983; accepted March 13, 1984.

Correspondence may be addressed to Anders Borgström, Department of Clinical Chemistry, University of Lund, Malmö, Sweden.

This research was supported by grants from the "Expressen" Prenatal Research Foundation and the E. T. Segerfalk's, A. Pählssons and Svensson's Foundations for Medical Research $\alpha_{1} \mathrm{AT}$ in a concentration of $\mathbf{3 0 - 2 0 0} \mu \mathrm{g} / \mathrm{liter}$, and small amounts of trypsinogen, 0-50 $\mu \mathrm{g} /$ liter. Three of four amniotic fluid samples from CF fetuses had very low concentrations of trypsin in complex with $\alpha_{1} \mathrm{AT}(<10 \mu \mathrm{g} /$ liter $)$, and only small amounts of trypsinogen ( $<10 \mu \mathrm{g} /$ /iter). Further prospective studies are needed to ascertain whether the determination of IRT in amniotic fluid may be of use in prenatal diagnosis of $\mathrm{CF}$.

\section{Abbreviations}

$\alpha_{1}$ AT, $\alpha_{1}$-antitrypsin

CF, cystic fibrosis

g.w., gestational week

IRT, immunoreactive trypsin

RIA, radioimmunoassay 